\title{
MATERIAEY
}

Hanna Grzesiak

Zaktad Historii i Metodologii Nauk o Kulturze

Instytut Kulturoznawstwa Wydziat Nauk Spolecznych

Uniwersytet im. Adama Mickiewicza, Poznań

\section{Tradycyjna edukacja dzieci żydowskich (wprowadzenie do problemu)}

Stuchaj, Izraelu, Pan jest naszym Bogiem - Panem jedynym. Będziesz mitowat Pana, Boga twojego, z całego swego serca, z catej duszy swojej, ze wszystkich swych sit. Niech pozostana w twym sercu te słowa, które ja ci dziś nakazuję. Wpoisz je twoim synom, będziesz o nich mówit przebywając $w$ domu, w czasie podróży, kładąc się spać $i$ wstając ze $s n u^{l}$. Owe słowa $\mathrm{z}$ Księgi Powtórzonego Prawa odmawiane podczas modlitwy porannej (szacharit) i wieczornej (maariw) będące jednocześnie fundamentem judaizmu są niejako kluczem do zrozumienia całej edukacji żydowskiej. Edukacja żydowska bowiem, jak zostanie przedstawione w niniejszym artykule, ma od czasów starożytności aż po współczesne charakter głównie religijno-moralny.

Przyjście na świat dziecka w żydowskiej rodzinie oznaczało zarówno w czasach starożytnych, jak i współcześnie ogromne szczęście, było bowiem błogosławieństwem i darem od Boga. $\mathrm{Z}$ tego też powodu bezdzietność uważano za jedno z największych nieszczęść, jakie może dotknąć człowieka. Jak czytamy w Talmudzie: osoba bezdzietna uważana jest za martwa ${ }^{2}$. To dzieci banim według popularnej gry słów są budowniczymi - bonim ${ }^{3}$. Budują nie tylko przyszłość rodziny, z której pochodzą, ale są, co istotne, gwarancją na przetrwanie całego narodu wybranego.

Chociaż Biblia nie wskazuje, ile dzieci powinno mieć małżeństwo, to opinie wśród żydowskich uczonych na ten temat są wyraźnie podzielone. Według Szammaja małżeństwo powinno mieć minimum dwóch synów i dwie córki. Hillel natomiast jest zdania, że wystarczy jeden syn i jedna córka ${ }^{4}$.

\footnotetext{
${ }^{1}$ Pwp 6:4-7.

2 Gen. R. 71.6

3 A. Cohen, Talmud, Warszawa 2002, s.182.

4 Yebamot 62a.
} 
Mimo że każde dziecko jest traktowane jako dar od Boga, to jednak szczególna radość panowała, gdy w rodzinie pojawił się syn. To on dziedziczył majątek - jak czytamy w Talmudzie - gdzie jest syn córka nie dziedziczy. To syn był podporą dla rodziców i miał przywilej studiowania Tory. Córka natomiast, to jak podkreśla Talmud: próżny skarb dla ojca, niepokoi się o nia i nie może spać w nocy; będac dzieckiem, niepetnoletnia boi się, żeby nie została uwiedziona; $w$ petnoletniości aby nie zeszła na zła drogę, później boi się, iż nie znajdzie męża, a jeśli będzie go mieć to, że będzie bezpłodna, a na starość martwi się aby nie uprawiała czarów ${ }^{6}$. Oprócz wymienionych powodów syn dodatkowo utrwalał nazwisko i tradycje rodziny, podczas gdy córka po zamążpójściu zmieniała nazwisko i tym samym stawała się członkiem innej rodziny z zupełnie innymi tradycjami ${ }^{7}$.

Zarówno w starożytności, jak i w czasach współczesnych, zwłaszcza w judaizmie ortodoksyjnym, dziecko było i jest cenione z trzech powodów: historycznego, teologicznego oraz społeczno-ekonomicznego ${ }^{8}$. Wedle tej koncepcji, z historycznego punktu widzenia, dziecko tworzy historię począwszy od swojej rodziny, poprzez środowisko, w którym żyje, na całym narodzie skończywszy.

W aspekcie teologicznym dziecko jest bożym zamysłem, zostaje bowiem ukształtowane jeszcze przed jego narodzeniem. Jak czytamy w Księdze Psalmów:

Ty bowiem utworzyteś moje nerki,

Ty utkałeś mnie w tonie mej matki ${ }^{9}$.

Oraz dalej, jak czytamy w Księdze Jeremiasza: Zanim ukształtowatem cię $w$ tonie matki, znałem cię, nim przyszedłeś na świat, poświęciłem cię ${ }^{10}$.

Również pod względem społeczno-ekonomicznym dziecko odgrywa istotną rolę. Zapewnia bowiem kolejną parę rąk do pracy, a dla rodziców jest gwarancją, że w chorobie i starości nie zostaną sami. Tora nakazuje nawet: Czcij ojca twego i matke twoja ${ }^{11}$ oraz Każdy z was będzie szanowat matkę $i$ ojca ${ }^{12}$. Co jednak oznacza czcić i szanować rodziców? Rabbi Baraita podaje trzy przykłady, aby zilustrować co należy rozumieć przez szacunek względem ojca: 1) syn nie powinien stać ani siedzieć na miejscu ojca; 2) syn nie powinien zaprzeczać opiniom ojca; 3) kiedy ojciec jest uwikłany w spór z inną osobą, syn nie powinien decydować, która z osób ma rację. Jeśli natomiast chodzi o oddawanie czci, to dzieci powinny: 1) dostarczać rodzicom pożywienie; 2) dostarczać ubranie; 3) towarzyszyć im przy wchodzeniu i wychodzeniu z pokoju ${ }^{13}$. A. Unterman dodaje, że dzieci musza

5 Sanhedryn 116 b.

6 Sanhedryn 100 b.

7 E. Ebner, Elementary education in ancient Israel, New York 1956, s. 29.

8 Por. A. Eckmann, Dziecko w Biblii, w: Rodzina w starożytnym Rzymie, materiaty z konferencji naukowej Zacisze 20-21.05 1991, red. J. Jundziłł, Bydgoszcz 1992, s.209.

9 Ps 139:13.

10 Jr 1:5.

11 Wj 20:18.

12 Lb 19:3.

${ }^{13}$ L. Jacobs, Jewish law, New York 1968, s. 73. 
wyrażać się o rodzicach z szacunkiem, nawet po ich śmierci ${ }^{14}$. Wszystko to sprawiało, że małżeństwo mające dziecko posiadało pozycję uprzywilejowaną w stosunku do tego, które było bezdzietne, które uważane było za gorsze i bezwartościowe. Bóg w przekonaniu Izraelczyków błogosławi tylko tym, którzy mają liczne potomstwo. Z tego też powodu zdarzało się niejednokrotnie, iż małżeństwa bezdzietne były odsuwane na margines społeczeństwa, gdyż sądzono, iż brak dzieci jest karą za ich grzechy.

Hebrajski termin chinuch przeważnie jest tłumaczony jako edukacja. Odnosząc się jednak do judaizmu jest to pojęcie o wiele szersze. Oznacza ono bowiem nie tylko zdobywanie wiedzy, ale również, a może i przede wszystkim naukę, której celem jest życie zgodne z zasadami prawa żydowskiego ${ }^{15}$.

Edukacja żydowska nie zaczyna się w szkole, lecz w domu. To rodzice, w szczególności zaś ojcowie, mają obowiązek wprowadzić swoje dzieci w życie religijne i dawać im podstawy właściwego wychowania. Jak dodaje A. Simon, na edukację dziecka składają się trzy elementy: Bóg, dom oraz Tora ${ }^{16}$. To właśnie w domu dziecko pierwszy raz spotyka się z wychowaniem religijnym, które tak naprawdę jest podstawą całej edukacji żydowskiej. To w domu dziecko od wczesnego ranka aż do wieczora obserwuje, modlącego się i całymi dniami studiującego Torę ojca oraz matkę, zajmującą się domem i zapalającą co tydzień świece szabatowe. To rodzice zatem są pierwszymi i jednocześnie najważniejszymi dla dziecka nauczycielami. Talmud zwraca również uwagę, że mowa dziecka na ulicy jest mowa jego ojca i matki ${ }^{17}$. Dlatego też właściwa mowa i zachowanie dziecka świadczą o jego dobrym wychowaniu przez rodziców.

O ile w pierwszych latach swojego życia dziecko pozostawało pod wyłączną opieką matki, bawiąc się z rówieśnikami na ulicy czy placu, o tyle później samymi tylko córkami do ich zamążpójścia opiekowały się matki, ucząc je i przygotowując do roli przyszłej żony i matki ${ }^{18}$. Jak wskazuje Talmud, dziewczynki uczyły się gotować, zmywać naczynia, piec ciasta, opiekować się dziećmi, ścielić łóżka oraz robić na drutach ${ }^{19}$. Ojciec natomiast odpowiedzialny był za wychowanie syna ${ }^{20}$. Jak czytamy w Talmudzie: ojciec jest zobowiazany obrzezać go, wykupić ${ }^{21}$, nauczyć go Tory, znaleźć mu żonę oraz nauczyć go rzemiosta ${ }^{22}$. Przez nakaz zawarty w Księdze Powtórzonego Prawa: będziesz je (przyka-

${ }^{14}$ A. Unterman, Żydzi. Wiara i życie, Warszawa 2002, s. 104.

15 Por. G. Robinson, Essential Judaism-a complete guide to beliefs, customs, and rituals, New York, London, Toronto, Sydney 2001, s. 154.

16 A. Simon, Jewish education in the past, Washington 1909, s. 9.

17 Ibidem, 56b.

18 Por. H. Daniel-Rops, Życie w Palestynie w czasach Chrystusa, Warszawa 2001, s.100.

19 Mishnah Ket. 5, 5

${ }^{20}$ Warto w tym miejscu zaznaczyć, że w innych starożytnych cywilizacjach za wychowanie dziecka również był odpowiedzialny ojciec. Wyjątek jedynie stanowiła Sparta, gdzie wychowanie dziecka spoczywało na państwie. Por. Ebner E., op.cit., s. 43.

${ }^{21}$ Ceremonia wykupienia - pidjon ha - ben odbywa się 30 dni po narodzinach dziecka. Kapłan podczas uroczystości pyta ojca czy woli zachować syna, czy też pięć srebrnych monet na jego wykup. Ojciec oczywiście wybiera syna i pieniądze przekazuje kapłanowi. Ceremonia ta nie odbywa się, kiedy pierwsza w rodzinie urodziła się dziewczynka oraz kiedy chłopiec przyszedł na świat w wyniku cesarskiego cięcia.

${ }^{22}$ Kiddushin 29a. 
zania) wpajał swoim dzieciom ${ }^{23}$ oraz opowieści o cudach Jahwe, które uczynił swojemu ludowi wybranemu, ojciec wskazywał dziecku korzenie jego religii i pilnował, aby wszystko, co ono czyni, było podporządkowane Bogu. Ojciec odpowiedzialny był również za to, aby najwcześniej jak to możliwe nauczyć swoich synów modlitwy szma - najważniejszej żydowskiej modlitwy, o czym cztery razy wspomina Tora ${ }^{24}$.

Sieroty również miały możliwość, a wręcz obowiązek studiowania Tory. Cała gmina musiała bowiem dołożyć wszelkich starań, aby zastąpić im rodziców, w szczególności zaś ojca. W czasach starożytnych dzieci te chodziły do specjalnych szkół, które nazywane były Talmud - Tora, a nauczyciele byli opłacani z funduszy organizacji dobroczynnych lub gminnych ${ }^{25}$.

O ile współcześnie kobiety, w niektórych nurtach i odłamach judaizmu mają dostęp do edukacji religijnej, o tyle w czasach biblijnych obowiązek edukacji dotyczył tylko chłopców, ze szczególnym naciskiem na synów pierworodnych, którzy podobnie jak pierwociny żniw należały do Jahwe. Jak czytamy w Genesis: Poświęćcie Mi wszystko pierworodne. U synów Izraela do Mnie należeć będa pierwociny łona matczynego - zarówno człowiek, jak i zwierze ${ }^{26}$. Jak dodaje A. Unterman - kształcenie dziewczynki w Torze było jakby uczeniem jej niemoralnego postępowania, ponieważ mogła posłużyć się swa wiedza dla lubieżnych celów ${ }^{27}$. Talmud natomiast podkreśla, że córka to próżny skarb dla ojca, niepokoi się o nia i nie może spać w nocy; będac dzieckiem, niepetnoletnia boi się, żeby nie została uwiedziona, w petnoletniości aby nie zeszła na zła droge, później boi się, iż nie znajdzie męża, a jeśli będzie go mieć to, że będzie bezpłodna, a na starość martwi się, aby nie uprawiała czarów ${ }^{28}$.

Rabbi Joszua ben Levi zwracał uwagę dzieciom, aby od jak najwcześniejszych lat uczęszczali do synagogi. Mówił do nich: Przychodźcie wcześnie do synagogi i opuszczajcie ja późno, dzięki temu możecie żyć długo ${ }^{29}$. Dziecko zatem od najmłodszych lat było uczone i przygotowywane, aby swoje życie i myśli poświęcić Bogu - i żyć zgodnie z przykazaniami, które ten mu przekazał.

Przez wieki etapy nauczania i wychowania dzieci nie ulegały zmianie. Co istotne, w niektórych środowiskach żydowskich, zwłaszcza tych ortodoksyjnych, wymogi te obowiązują do dzisiejszego dnia. Traktat talmudyczny, Pirke Awot - Pouczenia Ojców, wskazuje wyraźnie etapy dotyczące wychowania religijnego dziecka, które obowiązują także współcześnie w żydowskich środowiskach ortodoksyjnych. W wieku pięciu lat dziecko jest już zdolne do nauki Pisma, mając dziesięć lat może zacząć studiować Misznę. Trzynasty rok życia jest odpowiedni do przestrzegania przykazań, dlatego też w tym wie-

\footnotetext{
23 Pwp 6:7.

24 G. Robinson, op.cit., s.155.

25 Z. Borzymińska, Szkolnictwo żydowskie w Warszawie 1831-1870, Warszawa 1994, s. 9.

${ }^{26} \mathrm{Rdz} 13: 2$.

27 A. Unterman, Encyklopedia tradycji i legend żydowskich, Warszawa 2003, s. 81.

28 Sanhedryn $100 \mathrm{~b}$.

29 Berakhot $8 b$.
} 
ku odbywa się żydowska Bar Micwa ${ }^{30}$. Ostatnim już etapem jest wprowadzenie do studiowania Gemary, które powinno się rozpocząć w wieku osiemnastu lat ${ }^{31}$.

Pierwsza wzmianka o powstaniu szkoły ( beit ha sefer) pochodzi z 64 r. n.e. W okresie tym za sprawą arcykapłana Jozuego ben Gamala powstał najstarszy dekret mówiący o powstaniu powszechnej edukacji ${ }^{32}$. Jak czytamy w Talmudzie: we wczesnym systemie edukacji do czasów Jozuego ben Gamala dzieci byty uczone w domu przez swojego ojca. Następnie przekształcit on system, zakładając szkołe $w$ każdym mieście $e^{33}$. Owe szkoły nazywały się po hebrajsku bejt ha sefer, co w dosłownym tłumaczeniu znaczy tyle, co domy książki. Do szkół takich uczęszczać miały dzieci od szóstego czy też siódmego roku życia ${ }^{34}$. Ponieważ owe rozporządzenie tylko o parę lat wyprzedzało zniszczenie Jerozolimy, które miało miejsce w 70 r. n.e., prawdopodobnie nie było ono na terenie Palestyny przestrzegane. Praktykowane było jedynie przez gminy żydowskie żyjące w diasporze, czyli poza granicami kraju ${ }^{35}$. Oprócz tych publicznych istniały także prywatne szkoły. Mieszkańcy każdej gminy płacili specjalne podatki, które przeznaczane były na utrzymywanie owych szkół. Niestety do szkół tych mogli uczęszczać tylko najbogatsi Żydzi ${ }^{36}$.

Jest wielce prawdopodobne, że wprowadzenie powszechnego obowiązku szkolnego powstało z myślą o sierotach, które nie miały ojca i nie były w stanie samodzielnie zgłębiać tajników Tory. Hamnuna podkreśla, iż to właśnie przez zaniedbanie edukacji tych dzieci Jerozolima została zniszczona ${ }^{37}$. Chociaż Gamala zalecał, aby rozpocząć edukację w wieku sześciu czy siedmiu lat, to jednak zwykle dziecko rozpoczynało naukę mając pięć lat, powołując się tym samym na uczonych, którzy uważali, że tylko w tak młodym wieku nauka może przynieść najlepsze efekty. Również i obecnie współczesne koncepcje pedagogiczne i psychologiczne uważają, że jest to najlepszy wiek dla dziecka na zdobywanie wiedzy.

Na lekcjach korzystano z elementarza Reszit Daat oraz Biblii hebrajskiej38. Ta druga książka służyła głównie do nauki czytania, była też podręcznikiem do geografii, historii czy też literatury. Naukę czytania dzieci rozpoczynały od Księgi Kapłańskiej, ponieważ

\footnotetext{
${ }^{30}$ Bar Micwa jest najważniejszym wydarzeniem w życiu dorastającego chłopca. Od tego momentu chłopiec jest uważany za pełnoletniego pod względem religijnym. Spoczywa na nim obowiązek przestrzegania przykazań i wlicza się go do minjanu, czyli grupy 10 mężczyzn, która jest niezbędna, aby odprawić nabożeństwo i czytać Torę. Chłopiec jest również zobowiązany odmawiać trzy razy dziennie modlitwę oraz regularnie pościć w wyznaczone święta.

31 Por Pirke Awot 5,25.

32 Por. A. Cohen, op.cit., s.186.

33 Sanhedryn 19b.

${ }^{34}$ R. de Vaux, Instytucje Starego Testamentu, Poznań 2005, s.60.

${ }^{35}$ Mówiąc o diasporze żydowskiej jej początki sięgają czasów Pierwszej Świątyni Jerozolimskiej, a jej gwałtowny rozwój nastąpił w VI w. p.n.e. po niewoli babilońskiej.

${ }^{36}$ Ch. W. Reines, Public Support of Rabbis, Scholars and Students in the Jewish Past, „YIVO Annual of Jewish Social Science" (YIVO AoJSS) 1952, t.7, s.84.

37 Shabbat $119 b$.

38 Judaizm na określenie Biblii hebrajskiej używa słowa Tanach. Określenie to jest skrótem powstałym ze złożenia liter początkowych trzech części żydowskiego Pisma Świętego: Tora, która obejmuje pierwszych pięć ksiąg, tj. Księgę Rodzaju, Wyjścia, Kapłańską, Liczb oraz Powtórzonego Prawa, Newiim - część obejmująca Księgi Prorockie oraz Ketuwim, czyli część obejmującą Pisma. Czasem na określenie Pisma Świętego używa
} 
księga ta traktuje o składaniu ofiar i o rytualnej czystości. Uważa się, że dzieci są czyste, zatem nauka musi się rozpocząć właśnie od tej księgi ${ }^{39}$. Należy w tym miejscu zaznaczyć, że książki w starożytności należały do rzadkości. Przeważnie dostęp do nich miały dzieci z bogatych rodzin. W niektórych biedniejszych gminach nie było nawet wystarczającej liczby książek, dlatego też zdarzały się przypadki, że dzieci potrafiły czytać po hebrajsku tylko do góry nogami, ponieważ zawsze siedziały z drugiej strony książki ${ }^{40}$.

W czasach starożytnego Izraela, jak również w późniejszym okresie zwracano uwagę bardziej na rozwijanie umiejętności czytania niż pisania ${ }^{41}$. Dzieci, które miały dobrych nauczycieli, przeważnie pierwsze litery pisały na pergaminie bądź na specjalnych łupkach. Nauczyciel kreślił uczniom hebrajskie litery, które uczniowie kolorowali w środku. Na wyższym poziomie nauczania korzystano ze zwojów i fragmentów Tory, które nie były już używane w synagodze ${ }^{42}$.

Kolejnym ogniwem w procesie edukacji były szkoły zwane bejt ha midrasz. O ile w szkołach podstawowych (bejt ha sefer) uczono dzieci tylko Prawa Pisanego, o tyle tutaj uczono również Prawa Ustnego ${ }^{43}$.

Podobnie jak obecnie, tak i w czasach starożytnych, szkoły współcześnie nazywane elementarnymi czy też podstawowymi były w owym okresie nierozerwalnie związane z synagogą. Pedagogiem był chazan, który pełnił funkcję urzędnika synagogalnego ${ }^{44}$. Jego zadaniem było głównie przekazanie dzieciom religijnej wiedzy. Klasa szkolna liczyła przeważnie 25 uczniów. W przypadku większej liczby dzieci konieczne było wprowadzenie dodatkowego - tzw. specjalnego nauczyciela, który opłacany był przez społeczność ${ }^{45}$. W salach wszyscy uczniowie siedzieli w półkolu, tak aby nauczyciel mógł dobrze widzieć wszystkich uczniów. Nauczyciel siedział na podwyższonym krześle, a dzieci na niskich ławkach.

Widać wyraźnie, że kształcenie dzieci żydowskich w czasach starożytnych miało charakter głównie religijny. Ł. Kurdybacha stwierdza, że rezultatem jednostronnego charakteru programu nauczania szkół żydowskich było wpajanie uczniom fanatycznego przywią-

się też określenia Księgi Święte, bądź Tora, która w tym przypadku ma szersze znaczenie niż Pięcioksiąg i obejmuje wszystkie księgi. Por. A. Unterman., Żydzi..., s. 47.

39 Por. Lev. R. 7, 3

${ }^{40}$ A. Unterman, $\dot{Z} y d z i \ldots$, s. 58.

${ }^{41}$ Niewątpliwie chodziło tutaj o to, aby dziecko jak najszybciej rozpoczęło studiowanie świętych ksiąg. Umiejętność pisania rozwijana była głównie w specjalnych szkołach przeznaczonych dla szoferów - pisarzy, których głównym zajęciem było przepisywanie świętych ksiąg oraz fragmentów z Księgi Powtórzonego Prawa, które później były umieszczane w specjalnych pojemnikach, zwanych mezuzami.

42 Encyclopedia Judaica, Vol. 6, Jerusalem 1997, s. 404.

43 Istnieje przekonanie, iż Mojżesz na górze Synaj dostał od Boga nie tylko Torę Pisaną, ale również Torę Ustną, która była przekazywana z pokolenia na pokolenie. W momencie kiedy została zniszczona II Świątynia Jerozolimska i Żydzi ulegli rozproszeniu, zaistniała potrzeba spisania owej tradycji ustnej, aby Żydzi, którzy ulegli rozproszeniu również mieli do niej dostęp. W ten sposób powstało drugie najważniejsze po Biblii Hebrajskiej dzieło judaizmu - Talmud.

${ }^{44}$ Por. H. Daniel-Rops, op.cit., s. 56.

${ }^{45}$ W.M. Feldman, The Jewish Child; Its History, Folklore, Biology, Sociology, London 1917, s.283. 
zania do własnej religii i tradycji narodowych ${ }^{46}$. Oczywiście ten aspekt edukacji miał na celu przede wszystkim przeciwstawienie w późniejszym okresie kształtowania się judaizmu silnym wpływom kultury hellenistycznej, która w owym czasie była poważnym zagrożeniem dla religii Żydów.

Szkolna dyscyplina zarówno w starożytności, jak i w czasach współczesnych, wymaga od swoich uczniów punktualności oraz przestrzegania obowiązku szkolnego oraz zasad panujących w szkole. Jak wskazuje Talmud, uczeń powinien wiedzieć, kiedy należy przyjść i kiedy wyjść ze szkoły ${ }^{47}$. Nieobecność na zajęciach dłuższa niż trzy dni była niedopuszczalna ( wyjątek stanowiła jedynie poważna choroba, która uniemożliwiała uczestniczenie w zajęciach). Regularne uczęszczanie natomiast nagradzane było przez rodziców drobnymi upominkami ${ }^{48}$. W czasie lekcji uczniowie mają zakaz wstawania z miejsca bez pozwolenia nauczyciela. Melamed mógł odpowiadać uczniom jedynie na pytania dotyczące przerabianego materiału, wszelkie niezwiązane z tematem pytania były niewskazane. Uczniowie nie mogli także zadawać pytań nauczycielowi, gdy ten wchodził do szkoły. Jak również wskazuje traktat Kethuboth - do obowiązków dziecka należy dokładne przygotowanie się do zajęćc ${ }^{49}$.

Starożytne żydowskie nauczanie składało się z kilku etapów, w skład których wchodziło: słuchanie, posłuszeństwo, rozumienie, praktyka, uczenie się lekcji i samodzielne poszukiwanie. Owe poziomy przebiegały od najbardziej biernego aż do aktywnego, które stopniowo miały uniezależniać ucznia od nauczyciela ${ }^{50}$.

Jak uważano, to właśnie słuchanie było pierwszym i zarazem najważniejszym ogniwem w zdobywaniu wiedzy. Nie tylko w Izraelu, ale również w Egipcie czy też Mezopotamii mówiono, że umiejętność właściwego słuchania jest cechą mądrego człowieka ${ }^{51}$. Przypomina o tym również fragment z Księgi Przysłów: Mądry, stuchajac, pomnaża swa wiedzę, rozumny nabywa biegłości $i^{52}$. Z tego też powodu starano się, aby dziecko przez aktywne słuchanie potrafiło jak najszybciej samodzielnie formułować pytania, stawiać hipotezy i w końcu samodzielnie poszukiwać odpowiedzi na nie.

Na lekcjach w szkole stosowano metody mnemotechniczne, aby szybciej zapamiętać dany fragment tekstu. Warto przytoczyć tutaj fragment Talmudu, który pokazuje, w jaki sposób dzieci uczyły się alfabetu hebrajskiego. Powiadaja, że do domu nauki przychodza teraz dzieci, które recytuja rzeczy, jakich nie wypowiedziano nawet za czasów Jehoszuy Ben Nuna. Alef i Bet sa początkowymi literami dwóch wyrazów oznaczajacych «ucz się zrozumienia»; Gimel i Dalet - «bądź dobroczyńca dla ubogich». Dlaczego nóżka Dalet zwrócona jest do Gimel? aby wskazać, że biedak wyciaga ręce do swego dobroczyńcy ${ }^{53}$.

\footnotetext{
${ }^{46}$ Ł. Kurdybacha, Wychowanie starożytnych Żydów, w: Historia wychowania, red. Ł. Kurdybacha, t. I, Warszawa 1967.

${ }^{47}$ Erubin 54b.

48 W.M. Feldman, The Jewish Child..., s. 284.

49 Kethuboth 69.

${ }^{50}$ N. Shupak, Learning methods in ancient Israel, Vetus Testamentum, Leiden, 2003, LIII, 3, s. 426.

51 Ibidem, s. 417.

$52 \operatorname{Prz} 1: 5$

53 Shabbat. 104 a.
} 
Metody mnemotechniczne stosowano również, aby przypomnieć chociażby kolejność porządku sederowego. Za pomocą 15 słów, które rymowały się lub zaczynały na tę samą literę, dziecko było w stanie wymienić i przypomnieć wszystkie kroki Sederu (Kadesz, Urchac, Karpas, Jachac, Magid, Rachac, Moci, Maca, Maror, Korech, Szulchan Orech, Cafun, Barech, Halel, Nirca).

Nie tylko uczeń był zobowiązany do ciągłego powtarzania i uczenia się na pamięć fragmentów Tory. Obowiązek taki spoczywał również na nauczycielu, który musiał tak długo powtarzać lekcję póki uczeń jej w całości nie opanuje. Jak czytamy w Talmudzie: Nauczyciel musi powtarzać lekcję, dopóki uczeń jej nie opanuje." ${ }^{54}$, jak również kto powtarza swą lekcję sto jeden razy jest lepszy od tego kto powtarza ją sto razy ${ }^{55}$. Joszua Ben Karha dodaje także, że studiowanie Tory i nieprzeglądanie jej systematycznie jest podobne do człowieka, który sieje, ale nie zbiera żniwa ${ }^{56}$. Dalej, w tym samym fragmencie dodaje, że ten, kto czyta Torę, lecz nie pamięta jej, podobny jest do kobiety, która nosi swoje dziecko i zakopuje je ${ }^{57}$.

Podstawą było opanowanie alfabetu hebrajskiego, aby dziecko mogło jak najszybciej przejść do czytania bardziej złożonych tekstów religijnych. Dlatego też litery kojarzono z wyrazami, do których były one podobne. Na przykład pierwsza litera alfabetu alef, była przedstawiana jako mężczyzna, który nosi dzbany - jeden na rękach, do którego nalewa wodę a drugi na plecach ${ }^{58}$. Alfabetu, co ciekawe uczono na trzy sposoby. Tak więc jak podaje I.G. Marcus, dziecko uczyło się liter od pierwszej do ostatniej (od alef do taw) oraz odwrotnie, a także łączyło pierwszą literę alfabetu z ostatnią, drugą z przedostatnią itd. ${ }^{59}$ Ten ostatni sposób został wprowadzony później i prawdopodobnie zaczerpnięty od starożytnych Greków.

Zdarzało się bardzo często, że uczniowie uczyli się nawzajem alfabetu. Miało to miejsce głównie wtedy, kiedy uczeń rozpoczynał naukę czytania. Początkujący uczeń siadał obok starszego kolegi, który osiągną już „mistrzostwo” w dziedzinie alfabetu i ten uczył go poszczególnych nazw liter alfabetu, ich kształtu oraz wymowy ${ }^{60}$.

Duży nacisk kładziono na płynne czytanie. Niestety, znaczna część uczniów nie potrafiła biegle i szybko czytać, gdyż nie miała wcześniej odpowiedniego przygotowania. Zdarzało się także, iż sami nauczyciele nie mieli odpowiedniej wiedzy i nie potrafili przeczytać poprawnie tekstu. Znane są przypadki uczniów, którzy wiele czasu musieli poświęcić $\mathrm{z}$ innym nauczycielem, aby prawidłowo czytać6 ${ }^{6}$.

Jeśli chodzi o naukę pisania, to nauczyciele nie przywiązywali do niej zbytnio uwagi. Bardzo rzadko nauczyciel dawał uczniom wskazówki, jak należy poprawnie pisać. Zwią-

${ }^{54} \operatorname{Er} 54 b$.

${ }^{55}$ Hag 9b.

${ }^{56}$ Sanhedryn 99a.

${ }^{57}$ Ibidem.

${ }^{58}$ I. Fishman, The History of Jewish Education In Central Europe. From the End of the Sixteenth to the End of the Eighteenth Century, London 1944, s.90.

${ }^{59}$ Por. I.G. Marcus, Rituals of Childhood; Jewish Acculturation In Medieval Europe, Yale 1996, s. 35-36.

${ }^{60}$ I. Fishman, op.cit., s. 89.

${ }^{61}$ Ibidem, s. 90-91. 
zane to nierzadko było z różnym poziomem grupy od początkującej do zaawansowanej, co dodatkowo utrudniało rozpoczęcie nauki pisania. Najważniejszym bowiem elementem edukacji była nauka czytania, której celem było jak najszybsza lektura i jak najdoskonalsze czytanie ksiąg świętych.

Niektóre szkoły praktykowały naukę pisania, która obejmowała wszystkich uczniów, tylko i wyłącznie w okresie wakacji szkolnych ${ }^{62}$. W innych natomiast nauka w wakacje odbywała się dla tych uczniów, którzy mieli problemy w nauce. Dotyczyło to zwłaszcza uczniów w wieku trzynastu lat, którzy po naukach w chederze mieli dalej zamiar kształcić się w jesziwie ${ }^{63}$.

Chociaż studiowanie Tory i innych tekstów religijnych wypełniało znaczną część życia dziecka, to odnajdujemy także informacje, że był także czas na odpoczynek i zabawę. Sam Zachariasz wspomina o placach wypełnionych dziećmi ${ }^{64}$. Wykopaliska archeologiczne natomiast informują nas o licznie znalezionych grzechotkach, ozdobnych kulach oraz kościach do gry ${ }^{65}$. Literatura talmudyczna podaje również, że dzieci uwielbiały bawić się żołnierzykami ${ }^{66}$. Miszna wspomina, że małe dzieci bawiły się nawet szarańczami ${ }^{67}$.

W zależności od efektów w nauce, jakie osiągali, traktat Awot dzieli uczniów na cztery typy: szybko pojmujących i prędko zapominających, z trudem pojmujących i prędko zapominających, szybko pojmujących i powoli zapominających oraz z trudem pojmujących i szybko zapominających ${ }^{68}$.

Przez wiele wieków jedynym środkiem wychowawczym była kara fizyczna. Jej surowość jednak zmniejszała się wraz z wiekiem wychowanka. O ile początkujący uczeń był bity rózgą, o tyle starszy chłopak był karany rzemykiem od sandałów ${ }^{69}$. Wielokrotnie o tej metodzie wychowawczej czytamy w Talmudzie: Karcenia chłopcu nie żałuj, gdy rózga uderzysz - nie umrze $e^{70}$. Podobne fragmenty odnajdziemy również w Tanachu: Nie kocha syna, kto rózgi żałuje, kocha go ten, kto go w porę karci ${ }^{71}$; Rózga i karcenie udzielaja madrości, chłopiec zostawiony sobie przynosi wstyd matce ${ }^{72}$, jak również: Karć syna, a zapewni ci spokój i sprawi radość twej duszy $y^{73}$.

W czasach, począwszy od średniowiecza aż po czasy nowożytne nauczanie, podobnie jak w poprzednich wiekach, miało charakter powszechny. Edukacja obejmowała dwa poziomy: podstawowy oraz wyższy. Cheder (z hebrajskiego pokój, izba) był elementarną placówką prywatną, do którego uczęszczali chłopcy już od piątego, a czasem i czwartego

\footnotetext{
${ }^{62}$ A. Vide, Customs of Worms Community (brak daty i miejsca wydania), s. 118.

${ }^{63}$ I. Fishman, op .cit., s.91.

${ }^{64} \mathrm{Za} \mathrm{8:5.}$

${ }^{65}$ H. Daniel-Rops, op.cit., s. 102.

${ }^{66}$ Zebahim 88b.

${ }^{67}$ Mishnah Shab. 9:7.

68 Av 15a.

69 Ł. Kurdybacha, op.cit., s. 55.

${ }^{70}$ H. Daniel - Rops, op.cit. s. 100.

71 Prz 13:24.

72 Prz 29:15.

73 Prz 29:17.
} 
roku życia. Ów „pokój” mieścił się najczęściej w domu nauczyciela - melameda ${ }^{74}$. Zadaniem ojca było poszukanie oraz „wynajęcie” odpowiedniego nauczyciela dla swojego dziecka. Zdarzało się, że często nauczyciel uczył jedno dziecko. Jednakże miało to głównie miejsce wtenczas, kiedy rodzice był zamożnymi ludźmi i zależało im na jak najlepszym wychowaniu dziecka. Najczęściej jednak melamed uczył kilkoro dzieci. W tej drugiej sytuacji rodzice indywidualnie płacili odpowiednią sumę nauczycielowi za zajęcia, bądź też umawiali się na wspólne płacenie kwoty, przez co koszty rozkładały się równomiernie pomiędzy poszczególnymi rodzinami. W przypadku, kiedy rodziców nie stać było na utrzymanie melameda koszty edukacji pokrywała społeczność żydowska. Chociaż zawód ten nie był dobrze opłacany, to cieszył się dużym uznaniem społecznym, ponieważ to niejako na nim spoczywała odpowiedzialność za właściwe wychowanie synów Izraela. Do placówki tej uczęszczały dzieci, zgodnie z Pouczeniami Ojców, w wieku czterech i pięciu lat, aczkolwiek zdarzały się też i trzyletnie dzieci. Należy w tym miejscu zaznaczyć, że takie elementarne szkoły nie istniały w północnej Francji oraz w Niemczech. Nie było bowiem specjalnych budynków szkolnych ani specjalnych grup nauczycieli opłacanych przez gminę. Edukacja zatem była porozumieniem pomiędzy rodzicami a nauczycielem. Często zatem zdarzało się w tych częściach Europy, iż dzieci ze względu na brak nauczycieli, bądź też brak możliwości dojazdu do nauczyciela, który mieszkał w innej wiosce, nie miały możliwości nauki ${ }^{75}$.

W szkołach tych nie było jednego obowiązującego systemu nauczania, każdy pedagog posiadał własny program, który realizował. Przez pierwsze dwa lata dziecko uczyło się czytać i pisać oraz poznawało tajniki gramatyki. Kolejne lata były poświęcane na pamięciowe opanowanie Tory. Podobnie jak w starożytności, także i tutaj dzieci rozpoczynały naukę od Księgi Kapłańskiej i przechodziły do studiowania Księgi Rodzaju.

Należy w tym miejscu zwrócić uwagę, że chociaż podstawą programową realizowaną w szkołach były przedmioty religijne, to nie miało to odzwierciedlenia we wszystkich krajach. Średniowieczni Żydzi żyjący w Hiszpanii byli wysoce wykształceni zarówno w przedmiotach sakralnych, jak również świeckich. Dzięki częstym kontaktom z kulturą arabską większość Żydów znała w bardzo dobrym stopniu język arabski ${ }^{76}$.

Podobnie jak w chederze, tak i w Talmud-Torze nauka zaczynała się rano zaraz po porannej modlitwie. W przypadku ciężkich, mroźnych zim poranne lekcje nie odbywały się, bądź nauczyciel chodził z uczniami do synagogi. Między godziną 10-11 dzieci miały przerwę na posiłek, kolejna - na podwieczorek odbywała się koło godziny 14 . Wtenczas dzieci udawały się do swoich domów. Po powrocie uczyły się dalej, aż do wieczornej modlitwy, w której uczestniczył również i sam melamed ${ }^{77}$. Nierzadko zdarzało się, że dziecko bardzo późno chodziło spać, a wszystko po to, aby następnego dnia przyjść na zajęcia z dobrze opanowanym na pamięć fragmentem Tory. O ile dziewczynki w tym czasie wspólnie się bawiły lalkami, grały w klasy i uczyły się od swoich mam

\footnotetext{
${ }^{74} \mathrm{~W}$ języku hebrajskim słowo to pochodzi od czasownika nauczać.

75 E. Kanarfogel, Jewish education and society in the high Middle Ages, Detroit 1992, s.19.

76 Por. G. Robinson, op.cit., s.155-156.

77 Polski słownik judaistyczny, t. I, red. Z. Borzymińska, R. Żebrowski, Warszawa 2003, s. 281.
} 
prac domowych, gdyż zakazane im było studiowanie Tory, o tyle chłopcy pozbawieni byli takich rozrywek.

Kolejnym ogniwem w procesie edukacji były jesziwy (jeszyboty) (z hebr. posiedzenie). Początki tych szkół sięgają pierwszych wieków naszej ery, kiedy to w Palestynie i Babilonii powstawały liczne akademie, które kształciły w prawie religijnym. W Afryce Północnej i w Hiszpanii pierwsze jesziwy powstały już w VIII w. W Niemczech natomiast, gdzie była największa ich liczba, rozkwit przypada na XII-XIII w. W Polsce pierwsza jesziwa powstała dopiero w 1509 r. w Krakowie z inicjatywy Jakuba Polaka. Jednak najbardziej znaną i słynącą w całej Europie była ta, założona w Lublinie w 1518 r. przez ucznia Jakuba Polaka - Szachnę ${ }^{78}$.

Do placówek tych trafiali chłopcy w wieku trzynastu lat po uroczystości bar micwy i zostawali w nich do dwudziestu kilku lat. W przypadku kiedy mężczyzna ożenił się, nie mógł już studiować w jesziwie, tylko przechodził do kolelu - placówki o takim samym znaczeniu religijnym, ale przeznaczonej wyłącznie dla żonatych mężczyzn.

Współczesne jesziwy są oparte na programie edukacyjnym litewskich jesziw z XIX w. Pierwsza z nich została założona w 1802 r. w Wołożynie ${ }^{79}$. W placówkach takich uczniowie parami (chawruta) pracują nad danym fragmentem tekstu talmudycznego. Obowiązkowym elementem zajęć jest również wykład (sziur), wygłaszany najczęściej przed południem, przez przewodniczącego jesziwy, zwanego rosz jesziwa. Zdarzało się, że często nazywany był on również rektorem. Osoba ta cieszyła się ogromnym autorytetem wśród studentów. Rosz jesziwa mieszkał najczęściej w ciągu tygodnia ze swoimi studentami i troszczył się, aby panowały między nimi dobre relacje oraz aby zwracano uwagę na najbiedniejszych studentów i wspomagano ich w miarę możliwości finansowo ${ }^{80}$. Program, oprócz dalszego wnikliwego studiowania Tory, obejmował również analizę traktatów talmudycznych i licznych komentarzy. W ciągu wielu wieków studiowania Talmudu powstała metoda zwana pilpul (z hebr. pieprzny), której zadaniem było łączenie różnych, czasem nawet sprzecznych przedmiotów rozważań w celach porównawczych i dochodzenie do nowych sformułowań drogą analogii. Metoda była już dobrze znana w czasach talmudycznych, ale jej rozkwit przypada na XVI w. Zawdzięczamy go Jakubowi Polakowi, który był założycielem krakowskiej jesziwy ${ }^{81}$. Często spotykała się ona z ostrą krytyką ze strony uczonych. Żydowski teolog z Pragi - rabi Jehuda Loew - twierdził nawet, że osoby posługujące się pilpulistyką traciły czas na kłamstwa i byłoby lepiej, gdyby się uczyły stolarki $^{82}$. Również w Polsce miała ona wielu przeciwników i bardzo szybko stała się synonimem „scholastyki” i „bezsensownego dzielenia włosa na czworo" ${ }^{83}$. Powstałe już wspomniane litewskie jesziwy z XIX w. całkowicie zerwały z pilpulistyką. Coraz rzadziej

\footnotetext{
78 Ibidem, t. I, s. 678.

79 J. Cooper, The child in Jewish history, London 1996, s.280.

${ }^{80}$ Polski słownik judaistyczny, t. II, s. 439.

${ }^{81}$ I. Fishman, The History of Jewish Education In Central Europe. From the End of the Sixteenth to the End of the Eighteenth Century., London 1944, s.104.

${ }^{82}$ Cyt. za: A. Unterman, Żydzi..., s. 142.

${ }^{83}$ Polski słownik judaistyczny, t. II, op.cit., s.317.
} 
naucza się tą metodą, nadal jednak współcześnie jest ona praktykowana w ortodoksyjnych szkołach żydowskich.

Większość studentów kończyła jesziwę bez żadnych formalnych uprawnień. Naukę w niej traktowano jako obowiązek religijny, który był ściśle przestrzegany ${ }^{84}$. Tylko niewielki procent bachurim ${ }^{85}$ uzyskiwało smichę (hebr. wyświęcenie), czyli pozwolenie na nauczanie innych, jak również orzekanie w kwestiach prawa żydowskiego.

Celem artykułu było zarysowanie edukacji dzieci żydowskich z uwzględnieniem stosowanych metod nauczania praktykowanych w szkołach. Jak widać, poprzez wieki edukacja żydowska ulegała licznym przemianom, które spowodowane były wieloma czynnikami zewnętrznymi, jak: rozproszenie ludu żydowskiego, które nastąpiło w wyniku zburzenia świątyni jerozolimskiej, wpływy innych kultur czy też przemiany, które miały w miejsce w procesie kształtowania się myśli żydowskiej. Jedno wydaje się być niezmienne - cel edukacji żydowskiej, którym było i jest do tej pory bliższe poznanie Boga przez studiowanie Tory i Talmudu.

\section{Traditional education of Jewish children (an introduction to the problem)}

\section{Summary}

The birth of a child in a Jewish family, both in the ancient times and today, brings happiness not only to the parents themselves but also to the whole of the Jewish community. Children are a gift from God, they contribute to the prosperous future of the family they come from, but they also, what is essential, guarantee the continued survival of the chosen nation. Following this assumption, childless families were considered to be deficient, unsubstantial and were shunned from society because, as the Israelites believe, God blesses only those who have numerous offspring. The lack of children was often considered a curse, equated to punishment for sins and the absence of God in the family.

The present article introduces the reader to the principles of traditional education of Jewish children, outlines problems of child's education both at home, which is a fundamental basis for creating and shaping Jewish identity, and at school, where the emphasis is on transferring knowledge of religious and moral nature. Additionally, educational methods used both at family home and educational establishments are also discussed in the article.

\footnotetext{
${ }^{84}$ A. Unterman, Encyklopedia tradycji..., s. 128.

${ }^{85}$ Określenie to jest często używane wobec studentów.
} 